\title{
EVALUATION OF THE POSSIBLE CURATIVE EFFECT OF NIGELLA SATIVA LINN OIL ON EXPERIMENTALLY ACETAMINOPHEN-INDUCED HEPATOTOXICITY AND NEPHROTOXICITY IN ADULT MALE ALBINO RATS
}

By

\section{Hamed Mohammed Osman, Saad Mohammed Mohammed, Sayed Abd- El Reheim Sayed * and Ashraf Abd El-Aty Emara}

Departments of Medical Physiology and Pathology*, Al-Azhar Faculty of Medicine

\begin{abstract}
Background: There is a great realization that the use of herbs has been considered for the treatment of human diseases such as heptotoxicity and nephrotoxicty since ancient times. Nigella sativa (NS) is one of the most important medicinal plants having strong antioxidant properties.
\end{abstract}

Objectives: Study the possible curative effect of Nigella sativa linn (NSL) oil on experimentally acetaminophen-induced hepatotoxicity and nephrotoxicity in adult male albino rats.

\begin{abstract}
Materials and Methods: Fifty adult male albino rats of local strain were chosen as an animal model for this study. They were divided into five equal groups: Negative control group, Positive control group, NsL oil group, Acetaminophen-treated group and Acetaminophen + NsL oil-treated group. Heptotoxicity and nephrotoxicty was induced by oral administration of acetaminophen. At the end of the experiment (24 days), blood samples were obtained for measuring of liver functions (ALT, AST and total bilirubin), kidney functions (serum creatinine and blood urea) and TNF $\alpha$. Animals were sacrificed; livers and kidneys were obtained for histopathological examination, immunofluorescence analysis for Tansforming Growth Factor- $\beta$ (TGF- $\beta$ ) and measurement of tissue level of malondialdehyde (MDA) in both liver and kidney.
\end{abstract}

Results: Acetaminophen-treated group and Acetaminophen + NsL oil-treated group showed significant increases in ALT, AST, total bilirubin serum creatinine,urea, TNF $\alpha$ and tissue MDA in both liver and kidney compared to Negative control group and Positive control group. Acetaminophen+NsL oil-treated group, when compared to Acetaminophen-treated group, showed a significant decrease in all previous parameters. Histopathological examination revealed appearance of partial improvement and evidence of some regeneration of both liver and kidney tissues of Acetaminophen + NsL oil-treated group in comparison with Acetaminophen-treated group in addition to immunofluorescence staining of expression of TGF $\beta$ in hepatocytes was improved in Acetaminophen + NsL oil-treated compared to Acetaminophen treated group, but there was no difference in the immunofluorescence staining of kidney sections of the previous groups.

Conclusion: Nigella sativa linn oil has a curative role in regeneration of liver and kidney tissues in acetaminophen-induced hepatotoxicity and nephrotoxicity.

Key words: Nigella sativa linn oil, acetaminophen, hepatotoxicity and nephrotoxicity. 


\section{HAMED MOHAMMED OSMAN et al.}

\section{INTRODUCTION}

End-stage liver disease (ESLD) is a devastating condition with multiple etiologies. However, epidemiological data indicate an increasing worldwide prevalence of liver cirrhosis, related to chronic infection by hepatitis $\mathrm{C}$ or $\mathrm{B}$ viruses, alcohol consumption and nonalcoholic fatty liver disease (Parola et al., 2008). Currently, the only curative treatment is liver transplantation (Friedman, 2008). Many people around the world have been afflicted by some type of liver lesions including fatty liver, nonalcoholic steatohepatitis, hepatitis with its types (A, B, and C), cirrhosis and hepatocellular carcinoma (Kim et al., 2013). Fibrosis, and in certain, cirrhosis represent the final end point of chronic liver tissue injury, in which chronic inflammation leads to the formation of scar tissue, loss of tissue architecture, and organ failure (Trautwein et al., 2015). Liver fibrosis is one of the leading causes of morbidity and mortality worldwide (Kandeel et al., 2017).

Chronic renal failure is a complication defined as progressive disturbance of kidney function over time and is characterized by abolishing the ability of the body to remove soluble waste resulting in the accumulation of "uremic toxins" (Rafieian-Kopaie and Nasri, 2013). Acute kidney injury is commonly described as a sudden decline in kidney function, its clinical manifestation appears as a reversible acute rise in nitrogen waste products, measured as blood urea nitrogen and serum creatinine levels over a period of hours to weeks (Ghosh et al., 2014).

It is well detected that chronic renal failure is an inflammatory illness and uremic toxins have the main role in creating the inflammatory milieu (Amini et al., 2012 and Ghosh et al., 2014). Kidney fibrosis is generally considered as activation and proliferation of interstitial area and by excessive synthesis and aggregation of extracellular matrix components, containing fibronectin and collagen. Likewise, the phenotypic changes that attribute to acute renal failure comprise inflammatory response and oxidative stress. Slowing the rate of progression of chronic renal failure and promoting the recovery of acute kidney injury is a critical part of the management of these two diseases (Nasri, 2013).

Acetaminophen (Paracetamol; N-acetyl-paminophenol) is an active metabolite of phenacetin. It has analgesic and antipyretic effects, but has an only weak anti-inflammatory effect. It is a weak nonselective cyclooxygenase inhibitor which has an excellent oral bioavailability. Acetaminophen is well-tolerated at therapeutic doses but at overdose and chronic use may cause hepatic and renal damage (Grosser et al., 2011). Use of acetaminophen in therapeutic doses is safe, rapid and almost completely absorbed from the gastrointestinal tract, but overdose of the drug leads to lifethreatening or fatal hepatic necrosis and renal failure (Bunchorntavakul and Reddy, 2013). Acetaminophen is now the most common drug in self-poisoning, with a high rate of morbidity and mortality (Pettie and Dow, 2013). Many cases of poisoning with $\mathrm{N}$-acetyl-p-aminophenol (APAP) in humans and animals have been reported (Gulmez et al., 2013).

This use of herbal plants as alternative medicine over centuries remains a popular 
choice for primary health care (Vanamala et al., 2012). Nigella (NS) sativa is a spice native to Mediterranean region. The used part of plant is the seeds which are utilized worldwide for edible and medicinal applications (Cemek et al., 2008).

Nigella sativa is one of the most popular, safe, non-detrimental, cytoprotective, and widely used as medicinal plant all over the world. NS is a flowering plant with dark-crescent shaped seeds and belongs to the family Ranunculaceae which commonly grows in North Africa and Asia (Kotb et al., 2017). The NS seeds have been used along many centuries as a medicinal plant and as a food additive (Ijaz et al., 2017).

A long list of studies has been conducted, and concluded that most of the anti-inflammatory effects are derived from the thymoquinone, which can be found abundantly in the seeds of Nigella sativa. Nevertheless, Nigella sativa along with its derivative products were used as treatment for liver diseases, rheumatism, as well as relevant inflammatory disorders (AlKhalaf and Ramadan, 2013).

The present study aimed to understand the pathophysiology of liver and kidney failure, and also elucidating the effects and possible mechanisms of NsL oil in attenuation of hepatotoxicity and nephrotoxicity.

\section{MATERIALS AND METHODS}

Experimental animals: This study was done in the postgraduate laboratory of Medical Physiology Department, Faculty of Medicine, Al-Azhar University on 50 adult male albino rats of local strain obtained from Helwan animal house, used in the present work. The rats weighing from 120 to 140 grams, kept for 10 days to adapt to conditions in the lab before the start of any experimental procedure. Each two rats were housed in a cage $(20 \times 32 \times 20 \mathrm{~cm})$. They were fed the standard balanced diet with water ad lib with normal dark/light cycle.

Experimental protocol: The animals were divided into 5 equal groups (10 rats each) in this study as follows:

Group I (Negative control group): Each rat received only regular diet and tap water for 21 days to measure the basic parameters.

Group II (Positive control group): Each rat received $1 \mathrm{ml}$ corn oil/day, orally for 21 days (Elkhateeb et al., 2015).

Group III (NsL oil group): Each rat received $(1 \mathrm{ml} / \mathrm{kg} \mathrm{NsL}$ oil dissolved in 1 $\mathrm{ml}$ corn oil/day), orally for 21 days (Assayed, 2010).

Group IV (Acetaminophen-treated group): Each rat was treated with Acetaminophen $(500 \mathrm{mg} / \mathrm{kg})$, orally for 3 days for induction of hepatotoxicity and nephrotoxicity (Gopi et al., 2010), then received $1 \mathrm{ml}$ corn oil/day, orally for the next 21 days.

Group V (Acetaminophen + NsL oiltreated group): Each rat was treated with Acetaminophen for 3 days in the previous dose then received $1 \mathrm{ml} / \mathrm{kg} \quad \mathrm{NsL}$ oil dissolved in $1 \mathrm{ml}$ corn oil/day orally for the next 21 days.

At the time of sacrification, rats were anesthetized with isoflurane and then, blood samples were collected from the retro-orbital plexuses. The liver and kidneys of each rat were dissected out carefully. Each specimen was divided into 
two parts; one part was kept frozen at $-80 \circ \mathrm{C}$ till they were used for measurement of MDA content, and the other part was preserved for histopathological examination.

Methods: Hepatotoxicity and nephrotoxicity were induced by oral administration of acetaminophen 500 $\mathrm{mg} / \mathrm{kg}$ for 3 days according to (Gopi et al., 2010). Acetaminophen was dissolved in boiling water (USP31, 2007).

\section{Preparation of Nigella sativa linn oil:}

Extraction of $\mathrm{N}$. sativa oil from $\mathrm{N}$. sativa seeds was done according to the method described by (Pal et al., 2011).

Biochemical analysis of liver and kidney functions:

The blood samples were used for estimation of serum alanine transaminase (ALT) (Reitman and Frankel, 1957), aspartate transaminase (AST) (Thomas, 1998), serum total bilirubin (Mallay and Evelyn, 1937), blood urea (Orsonneau et al., 1992) serum creatinine (Fossati et al., 1983), and (TNF $\alpha$ ) determined by Enzyme Linked Immuno-Sorbent Assay (ELISA) according to the manufacturer's instructions of ELISA kits (Abcam, UK).

\section{Preparation of liver and kidney homogenate:}

Liver and kidney tissues were homogenized with 10 times (w/v) ice-cold $0.1 \mathrm{M}$ phosphate buffer ( $\mathrm{pH} 7.4$ ). Aliquots of homogenates were used to determine Malondialdehyde (MDA) was assayed (Ohkawa et al., 1979).
Immunofluorescence Analysis for Tansforming Growth Factor- $\beta$ (TGF及):

Slides containing liver and kidney tissue sections were handled and prepared for detection of TGF- $\beta$ by immunoflurecence microscope "Leica DM 5500B" (Abdel-Bakky et al., 2011).

\section{Histopathological examination of liver} and kidney tissues:

Autopsy samples taken from the liver and kidney of rats in different groups were prepared and stained by hematoxylin \& eosin, and Masson`s trichrome stains for routine examination the light electric microscope (Banchroft et al., 1996).

\section{Quantitative morphometric analysis:}

The area percentage of collagen fibers was measured in Masson's trichrome stained sections. The measurements were obtained using computer-based image analysis software (Leica Qwin 500; Imaging Systems, Cambridge, UK).

\section{Statistical Analysis:}

All the statistical analysis were processed using Statistical Program of Social Sciences (SPSS) for windows (version 17, SPSS Inc., Chicago, IL, USA), Values of the measured parameters were expressed as mean value \pm standard deviation (SD), and the differences and significance were verified by one-way ANOVA followed by the Fisher's least significant difference (LSD) post hoc test. $\mathrm{P}$ values $\leq 0.05$ were considered statistically significant. 


\section{RESULTS}

\section{Changes in liver functions ALT, AST and total bilirubin (TB) in different groups (figure 1):}

In group I, the mean \pm SD of ALT, AST and TB were $51 \pm 3.65$ units $/ 1,40.4$ \pm 2.5 units $/ 1$ and $0.37 \pm 0.058 \mathrm{mg} / \mathrm{dl}$ respectively.

In group II, the mean \pm SD of ALT, AST and TB were $60.5 \pm 3.63$ units $/ 1$, $50.8 \pm 4.26$ units $/ 1$ and $0.48 \pm 0.035$ $\mathrm{mg} / \mathrm{dl}$ respectively. There was an insignificant increase in ALT \& a significant increase in AST and TB in group II when compared with group I.

In group III, the mean $\pm \mathrm{SD}$ of ALT, AST and TB were $41.8 \pm 5.16$ units $/ 1$, $35.8 \pm 5.14$ units $/ 1$ and $0.33 \pm 0.048$ $\mathrm{mg} / \mathrm{dl}$ respectively. There was an insignificant decrease in ALT, AST and TB in group III when compared with group I and a significant decrease in ALT, AST and total bilirubin in group III when compared with group II.

In group IV, the mean \pm SD of ALT, AST and TB were $147.8 \pm 13.21$ units $/ 1$, $142.1 \pm 13.77$ units $/ 1$ and $0.86 \pm 0.14$ $\mathrm{mg} / \mathrm{dl}$ respectively. There was a significant increase in ALT, AST and TB in group IV when compared with group I, II and III.

In group $\mathrm{V}$, the mean $\pm \mathrm{SD}$ of ALT, AST and TB were $107.5 \pm 18.8$ units $/ 1$, $99.8 \pm 17.79$ units $/ 1$ and $0.79 \pm 0.055$ $\mathrm{mg} / \mathrm{dl}$ respectively. There was a significant increase in all parameters in group V when compared with group I, II and III, also there was a significant decrease in all parameters in group $\mathrm{V}$ when compared with group IV.
Changes in kidney functions serum creatinine and blood urea in different groups (figure 1):

In group $\mathrm{I}$, the mean $\pm \mathrm{SD}$ of serum creatinine and blood urea were $0.61 \pm$ $0.077 \mathrm{mg} / \mathrm{dl}$ and $36.1 \pm 3.6 \mathrm{mg} / \mathrm{dl}$ respectively.

In group II, the mean \pm SD of serum creatinine and blood urea were $0.82 \pm 0.2$ $\mathrm{mg} / \mathrm{dl}$ and $41.9 \pm 5.7 \mathrm{mg} / \mathrm{dl}$ respectively. There was an insignificant increase in group II when compared with group I in both serum creatinine and blood urea.

In group III, the mean \pm SD of serum creatinine and blood urea were $0.64 \pm$ $0.12 \mathrm{mg} / \mathrm{dl}$ and $35.3 \pm 4.2 \mathrm{mg} / \mathrm{dl}$ respectively. There was an insignificant decrease in group III when compared with group I and II in both serum creatinine and blood urea.

In group IV, the mean \pm SD of serum creatinine and blood urea were $6.63 \pm$ $0.77 \mathrm{mg} / \mathrm{dl}$ and $116.5 \pm 22.67 \mathrm{mg} / \mathrm{dl}$ respectively. There was a significant increase in group IV when compared with group I, II and III in both serum creatinine and blood urea.

In group $\mathrm{V}$, the mean $\pm \mathrm{SD}$ of serum creatinine and blood urea were $5.88 \pm$ $0.08 \mathrm{mg} / \mathrm{dl}$ and $94.2 \pm 14.4 \mathrm{mg} / \mathrm{dl}$ respectively. There was a significant increase in group $\mathrm{V}$ when compared with group I, II and III in both serum creatinine and blood urea, also there was a significant decrease in group $\mathrm{V}$ when compared with group IV in the same parameters. 
Changes in TNFa in different groups (figure 1):

In group I, the mean $\pm \mathrm{SD}$ of TNF $\alpha$ was $1.9 \pm 0.2 \mathrm{ng} / \mathrm{ml}$.

In group II, the mean $\pm \mathrm{SD}$ of TNF $\alpha$ was $2.74 \pm 0.52 \mathrm{ng} / \mathrm{ml}$. There was an insignificant increase in group II when compared with group I.

In group III, the mean $\pm \mathrm{SD}$ of $\mathrm{TNF} \alpha$ was $1.76 \pm 0.51 \mathrm{ng} / \mathrm{ml}$. There was an insignificant decrease

In group III when compared with group I and II.

In group IV, the mean $\pm \mathrm{SD}$ of TNF $\alpha$ was $10.69 \pm 2.67 \mathrm{ng} / \mathrm{ml}$. There was a significant increase in group IV when compared with group I, II and III.

In group $\mathrm{V}$, the mean $\pm \mathrm{SD}$ of $\mathrm{TNF} \alpha$ was $6.85 \pm 1.02 \mathrm{ng} / \mathrm{ml}$. There was a significant increase in group $\mathrm{V}$ when compared with group I, II and III, also there was a significant decrease in group V when compared with group IV.

Changes in liver and kidney tissue levels of MDA in different groups (figure 2):

In group I, the mean \pm SD of liver and kidney tissues levels of MDA were $12.4 \pm$ $1.86 \mathrm{nmol} / \mathrm{g}$ tissue and $10.26 \pm 1.65$ $\mathrm{nmol} / \mathrm{g}$ tissue respectively.
In group II, the mean \pm SD of liver and kidney tissues levels of MDA were 11.17 $\pm 1.75 \mathrm{nmol} / \mathrm{g}$ tissue and11.97 \pm 1.42 $\mathrm{nmol} / \mathrm{g}$ tissue respectively. There was an insignificant decrease in group II when compared with group I.

In group III, the mean \pm SD of liver and kidney tissues levels of MDA were $9.89 \pm 1.91 \mathrm{nmol} / \mathrm{g}$ tissue and $10.29 \pm$ $1.68 \mathrm{nmol} / \mathrm{g}$ tissue respectively. There was an insignificant decrease in group III when compared with group I and II.

In group IV, the mean \pm SD of liver and kidney tissues levels of MDA were $94.39 \pm 9.45 \mathrm{nmol} / \mathrm{g}$ tissue and $98.86 \pm$ $7.43 \mathrm{nmol} / \mathrm{g}$ tissue respectively. There was a significant increase in group IV when compared with group I, II and III.

In group $\mathrm{V}$, the mean $\pm \mathrm{SD}$ of liver and kidney tissues levels of MDA were 57.61 $\pm 4.88 \mathrm{nmol} / \mathrm{g}$ tissue and $42.67 \pm 3.77$ $\mathrm{nmol} / \mathrm{g}$ tissue respectively. There was a significant increase in group $\mathrm{V}$ when compared with group I, II and III, also there was a significant decrease in group $\mathrm{V}$ when compared compared with group IV. 


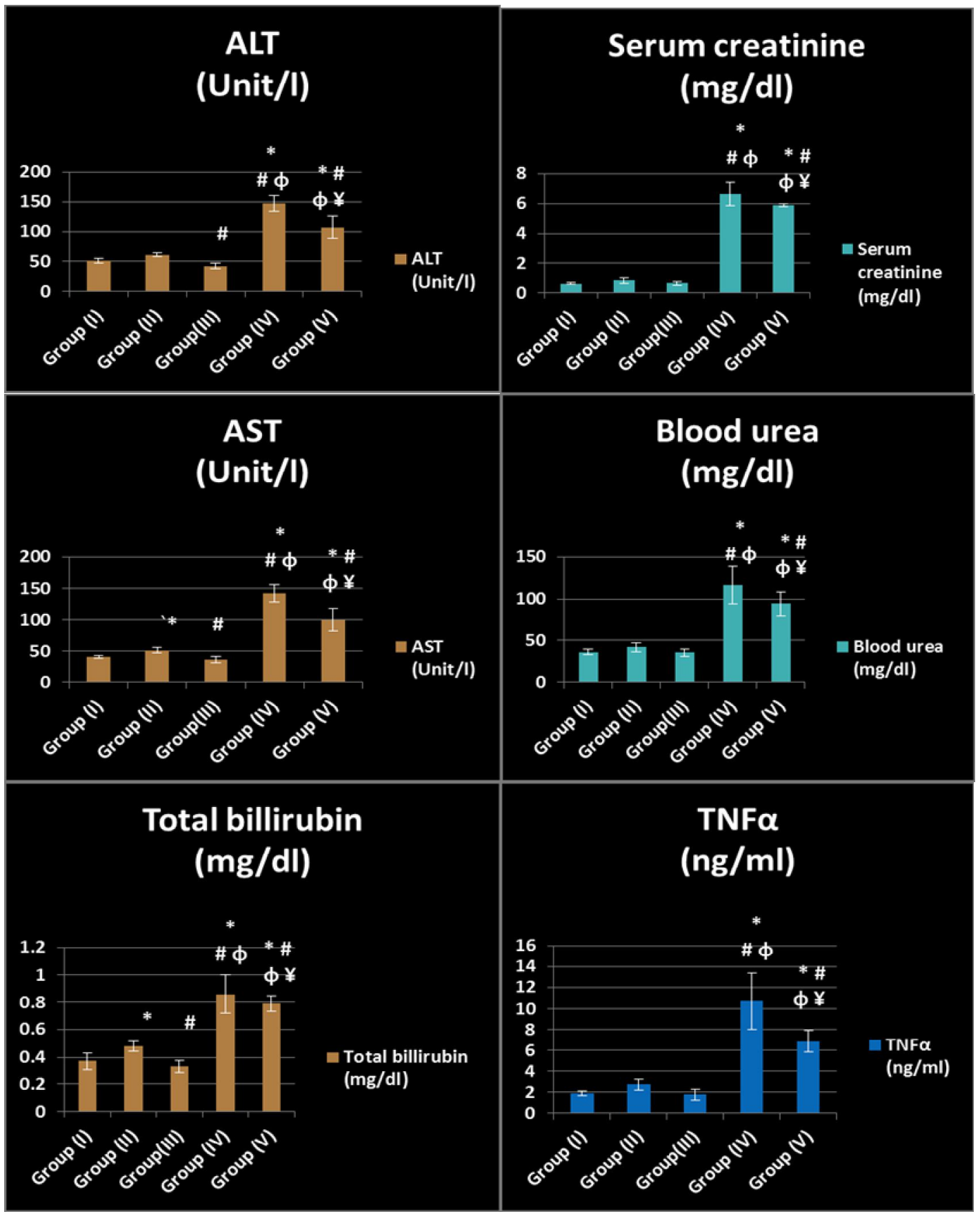

Figure (1): Changes in liver functions (ALT, AST, TB) and kidney functions (serum creatinine, blood urea) and TNFa in different groups (mean $\pm \mathrm{SD})$. 


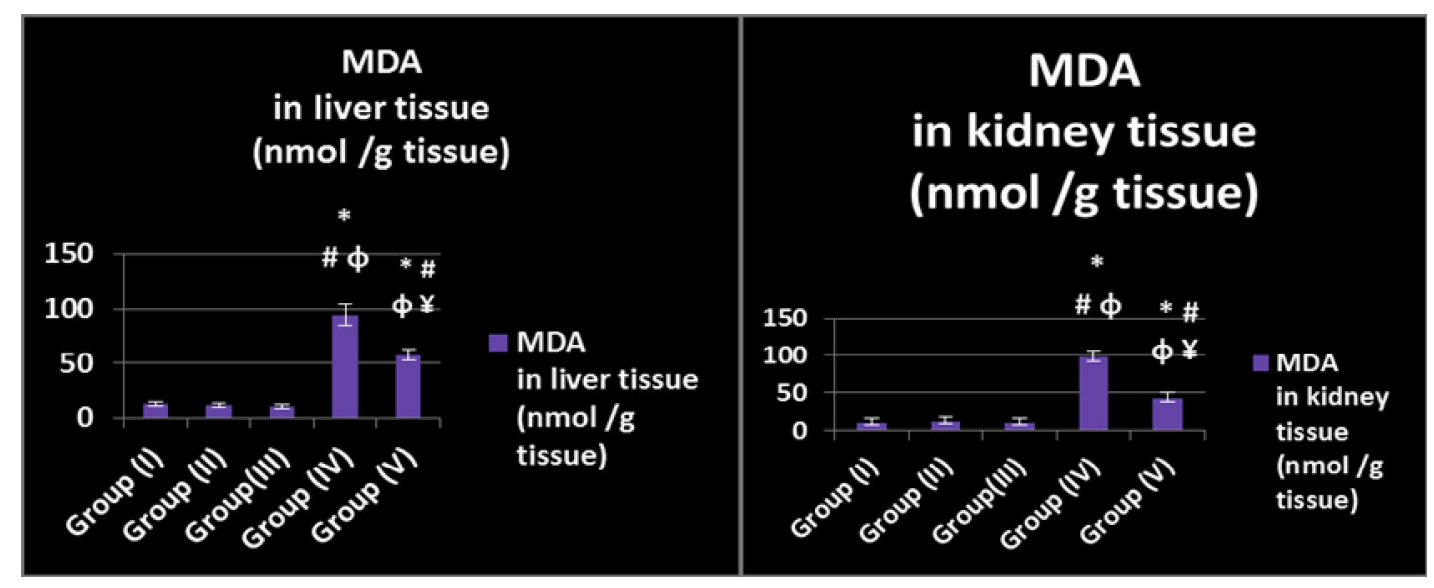

Figure (2): Changes in liver and kidney tissue levels of MDA in different groups (mean \pm SD).

*Significant with $\mathbf{G r} \mathbf{I}$

$\phi$ Significant with Gr III

Histopathological examination of the liver:

Group I (Negative control group) showed average hepatic architecture and hepatocytes arranged in single-cell cords (Fig 3a).

Group II (Positive control group) showed average hepatic architecture, minimally dilated central veins and average portal tracts (Fig 3b).

Group III (NsL oil group) showed average hepatic architecture, minimally dilated and congested central veins, average portal tracts and hepatocytes arranged in single-cell cords (Fig 3c).

Group IV (Acetaminophen-treated group) showed expanded portal tracts with markedly dilated blood vessels, dilated central vein with peri-venular cellular infiltrate, scattered apoptotic hepatocytes and scattered hepatocytes with micro-vesicular steatosis. No underlying fibrosis (Fig 3d).

Group V (Acetaminophen + NsL oiltreated group) showed expanded portal tracts with markedly dilated blood vessels, markedly dilated central veins, markedly

\section{\# Significant with Gr II $¥$ Significant with Gr IV}

congested blood sinusoids and vacuolated hepatocytes (Fig 3e).

Expression and localization of TGF $\beta$ of the liver:

It was observed that the expression is located in the cell membrane of hepatocytes. It was also noted that the expression occurred in areas with maximal lesions as necrosis and steatosis as follows:

Group I (Negative control group) showed mild cell membrane expression of TGF $\beta$ in hepatocytes (Fig 5a).

Group II (Positive control group) showed moderate cell membrane reactivity in peri-venular hepatocytes (Fig 5b).

Group III (NsL oil group) showed mild cell membrane reactivity in hepatocytes (Fig 5c).

Group IV (Acetaminophen-treated group) showed marked cell membrane reactivity in hepatocytes and cytoplasmic reactivity in stellate-shaped cells (Fig 5d).

Group V (Acetaminophen + NsL oiltreated group) showed mild cell membrane expression of hepatocytes, but 
the reaction was cytoplasmic and spindle and stellate-shaped cells (Fig 5e). increased in apoptotic hepatocytes,

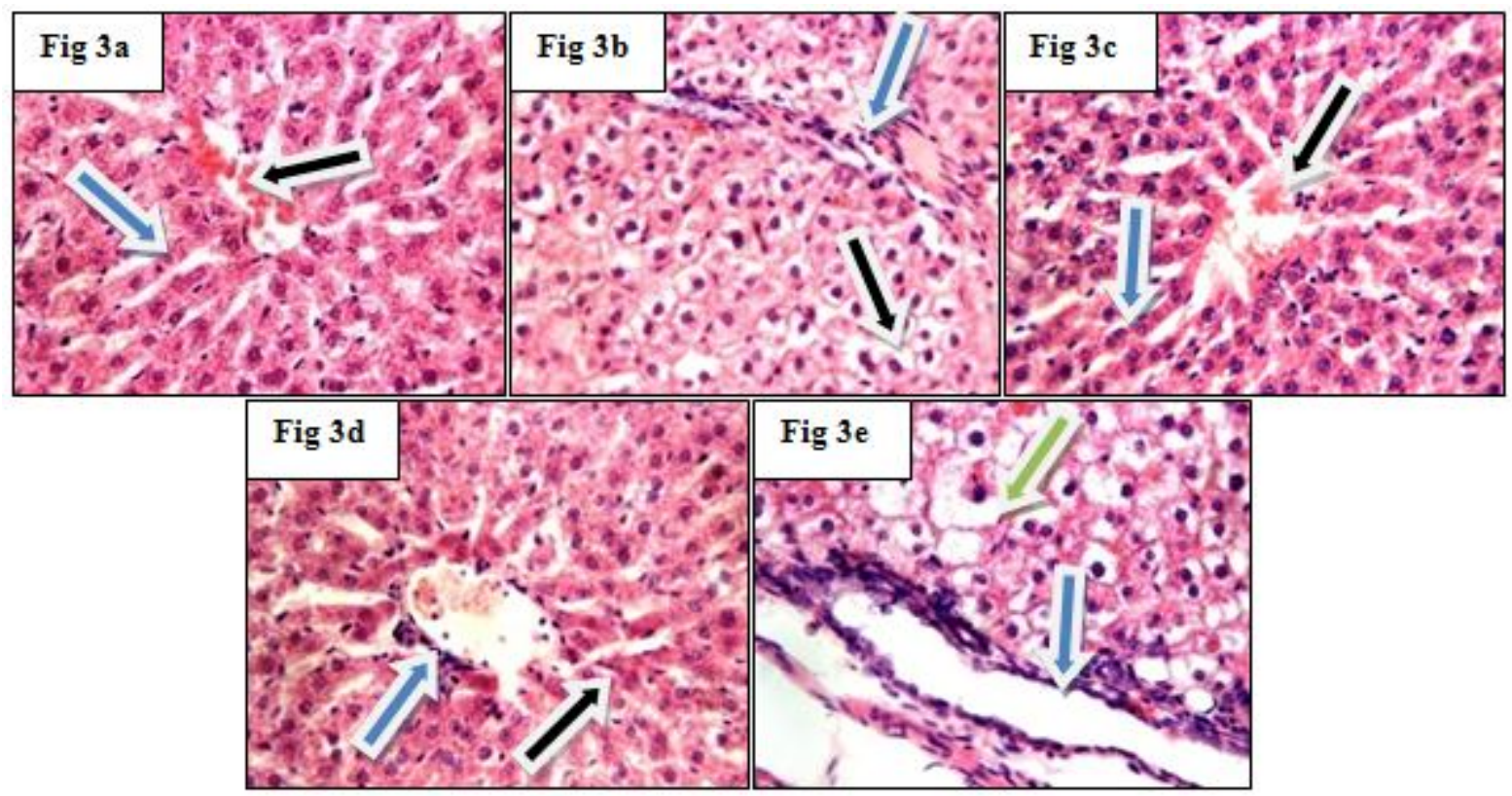

Figure (3): Histopathological examination of the liver by H\&E: Figs. (3a, b, c) related to GI, II, III showed average hepatic architecture, minimally dilated central veins (black arrow), average portal tracts (blue arrow) and hepatocytes arranged in single-cell cords (green arrow). Fig. (3d) related to GIV (Acetaminophen-treated group) showed dilated central vein with peri-venular cellular infiltrate (blue arrow) and scattered apoptotic hepatocytes (black arrows). Fig. (3e) related to GV (Acetaminophen + NsL oil-treated group) showed expanded portal tract with markedly dilated blood vessels (blue arrow), and vacuolated hepatocytes (green arrow).
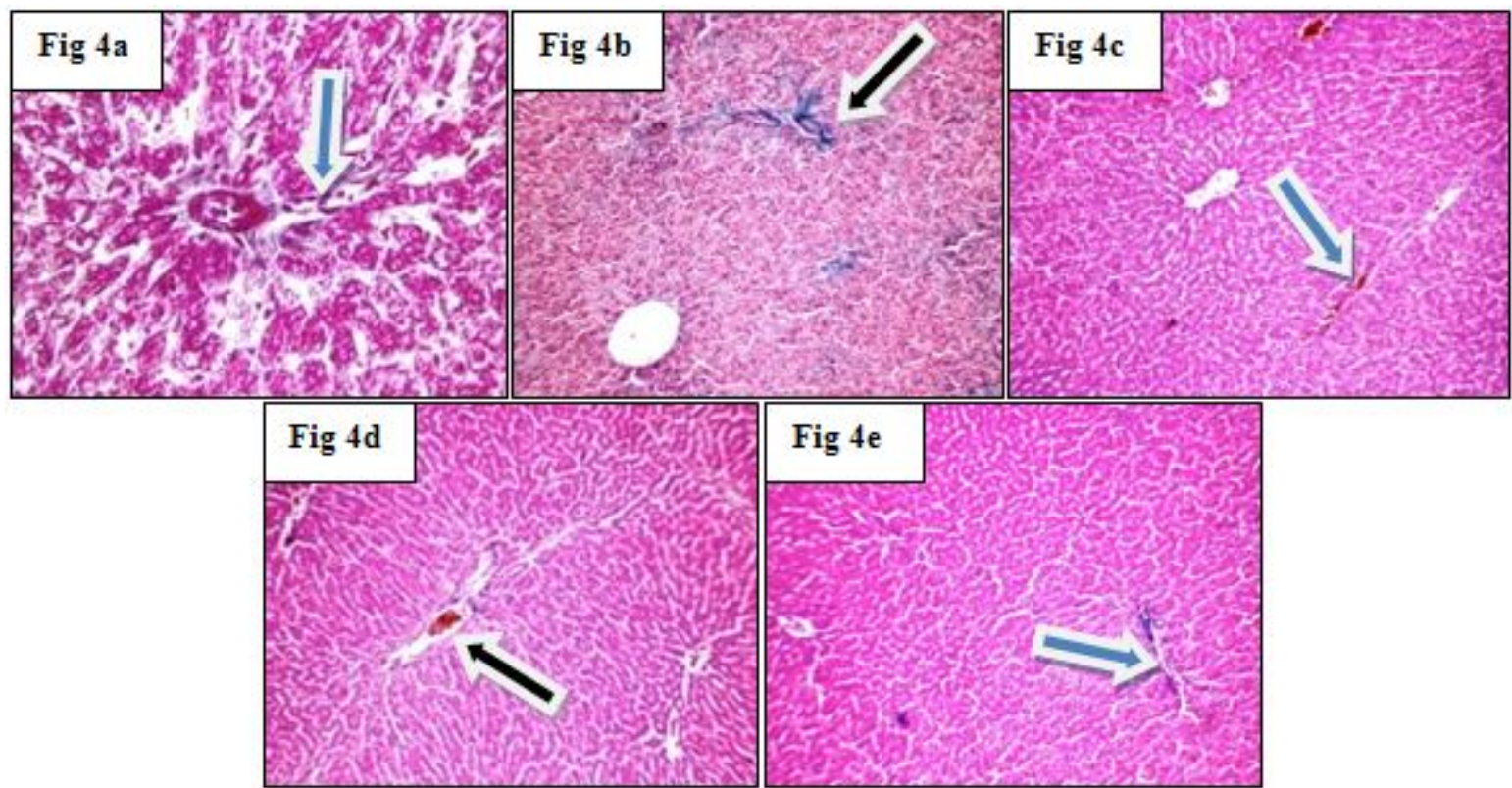

Figure (4): Histopathological examination of the liver by Masson trichrome stain: Figs. (4a, b, c, e) related to GI, II, III, GV showed portal tract with no fibrosis (black 
arrow). Fig. (4d) related to GIV (Acetaminophen-treated group) showed expanded portal tract with no fibrosis (black arrows).

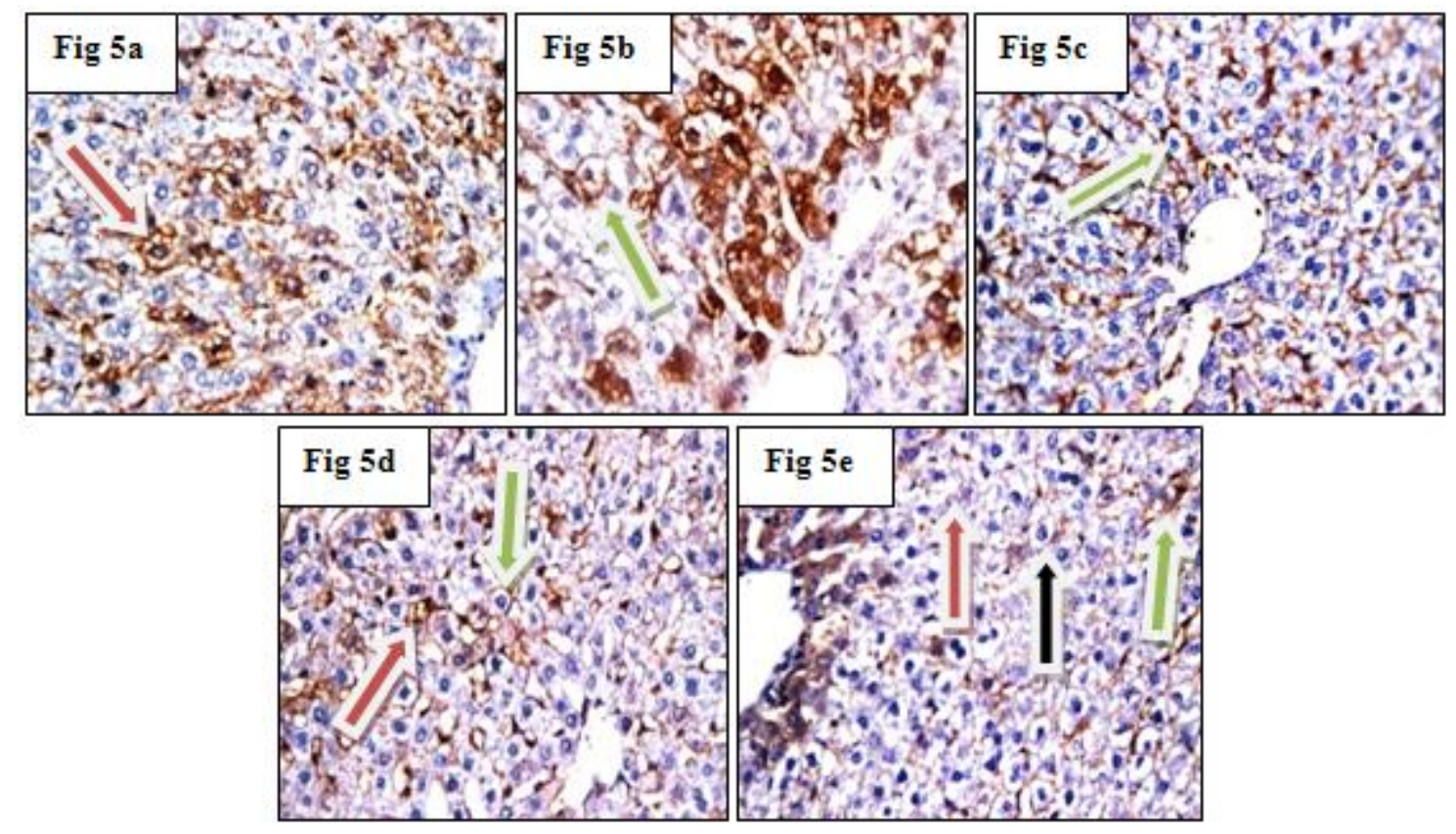

Fig (5) Immunofluorescence staining of liver by TGFß: Figs. (5a, b, c) related to GI, II, III showed mild to moderate cell membrane reactivity in hepatocytes (red arrow). Fig. (5d) related to GIV (Acetaminophen-treated group) showed marked cell membrane reactivity in hepatocytes (green arrows) and cytoplasmic reactivity in stellate-shaped cells (red arrows). Fig. (5e) related to GV (Acetaminophen + NsL oil-treated group) showed cytoplasmic reactivity in spindle-shaped cells (red arrow) and stellate-shaped cells (green arrow) with mild cell membrane reactivity (black arrow).

Histopathological examination of the kidney:

Group I (Negative control group) showed average glomeruli, tubules and interstitium (Fig. 6a).

Group II (Positive control group) showed average glomeruli with markedly dilated thin-walled blood vessels in the interstitium (Fig. 6b).

Group III (NsL oil group) showed less cellular glomeruli with mild vacuolar degeneration of tubular epithelium (Fig. 6c).

Group IV (Acetaminophen-treated group) showed distorted hypercellulr glomeruli with interstitium showing fibrous band with minimal cellular infiltrate and marked vacuolar degeneration of tubular epithelium (Fig. 6d).

Group V (Acetaminophen + NsL oiltreated group) showed distorted hypercellulr glomeruli with mild vacuolar degeneration of tubular epithelium (Fig. 6e).

Expression and localization of TGF $\beta$ of the kidney:

Group I (Negative control group) showed no reactivity in glomeruli or tubules (Fig. 8a).

Group II (Positive control group) showed mild reactivity in glomeruli and tubules (Fig. 8b).

Group III (NsL oil group) showed mild reactivity in glomeruli, with no reactivity in tubules (Fig. 8c). 
Group IV (Acetaminophen-treated reactivity in glomeruli and tubules (Fig. group) showed moderate reactivity in glomeruli and tubules (Fig. 8d).

8e).

Masson trichrome stain: showed mild glomerular and peri-tubular fibrosis in Group V (Acetaminophen + NsL oiltreated group) showed moderate group IV (Fig. 7d).
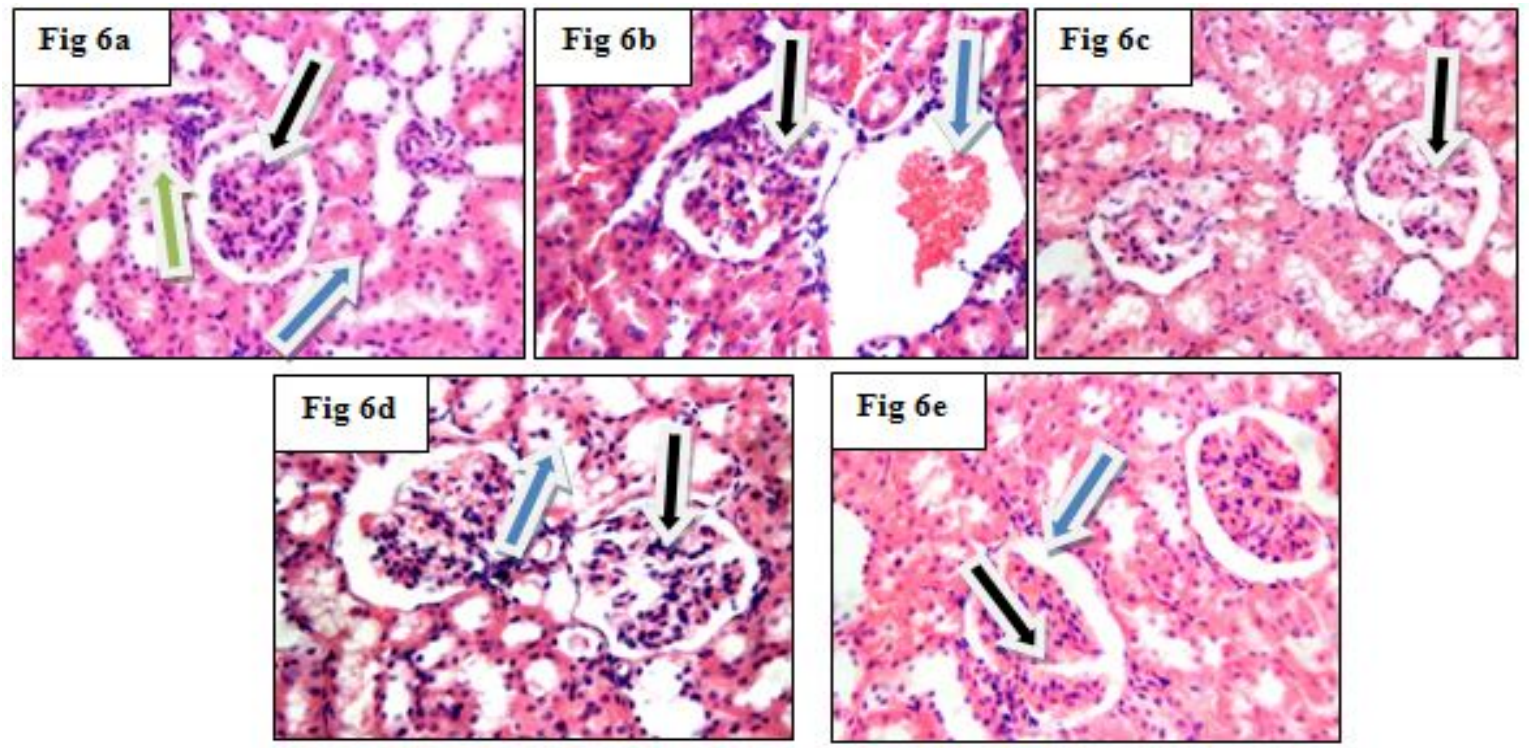

Figure (6) Histopathological examination of the kidney by H\&E: Fig. (6a) related to GI showed average glomeruli (black arrow) with average proximal (blue arrow) and distal tubules (green arrow). Figs. (6b, c) related to G II, III showed average glomeruli (black arrow) with dilated thin-walled blood vessel (blue arrow). Fig. (6d) related to GIV (Acetaminophen-treated group) showed distorted hypercellulr glomeruli (black arrow) with marked vacuolar degeneration of tubular epithelium (blue arrows). Fig. (6e) related to GV (Acetaminophen + NsL oil-treated group) showed distorted hypercellulr glomeruli (black arrows) with mild vacuolar degeneration of tubular epithelium (blue arrow).
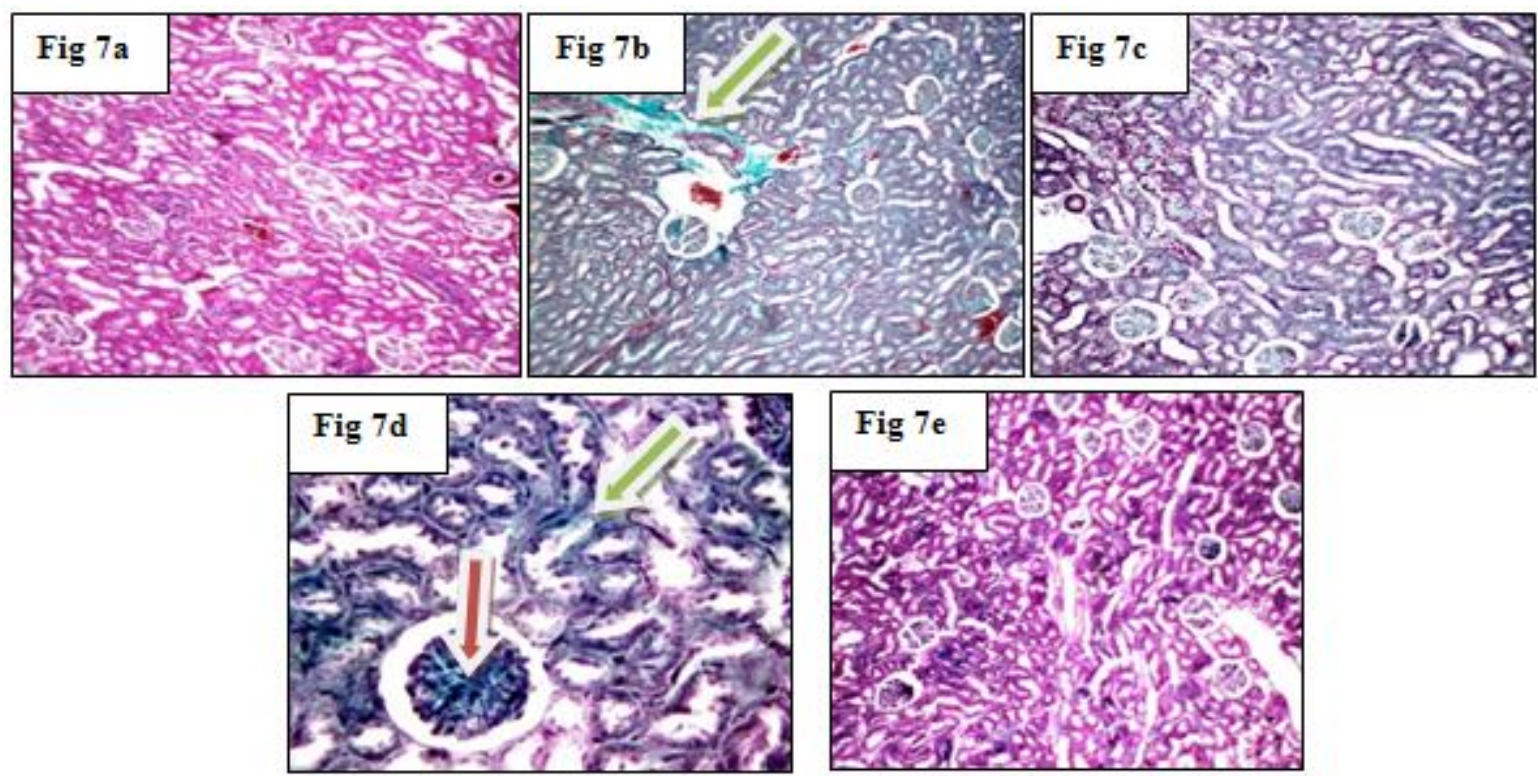

Figure (7) Histopathological examination of the kidney by Masson trichrome stain:

Figs. (7a, c, e) related to GI, II, III, GV showed renal tissue with no fibrosis. Fig. (7b) 
showed average renal tissue with mild positivity (green arrow). Fig. (7d) related to GIV (Acetaminophen-treated group) showed glomerular (red arrow) and peri-tubular fibrosis (green arrows).

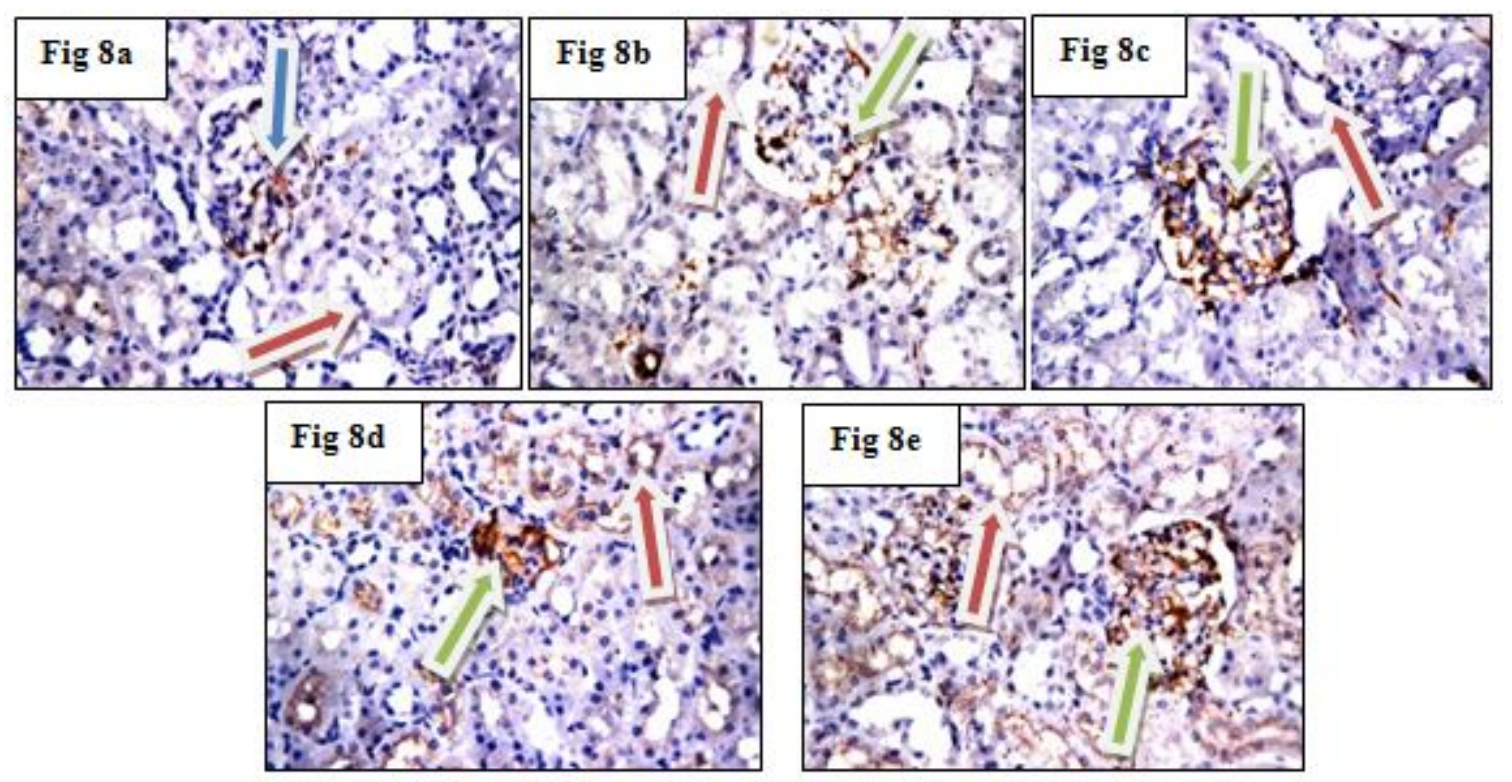

Figure (8) Immunofluorescence staining of kidney by TGFß: Fig. (8a) related to GI showed no reactivity in glomeruli (red arrow)or tubules (blue arrow). Figs. (8b, c) related to GII, III showed mild reactivity in glomeruli (green arrow) or tubules (red arrow). Figs. $(\mathbf{8 d}, \mathbf{e})$ related to GIV (Acetaminophen-treated group) and GV (Acetaminophen + NsL oiltreated group) showed moderate reactivity in glomeruli (green arrow) or tubules (red arrow).

\section{DISCUSSION}

The major objective of this study was to assess the possible benefit of Nigella sativa linn oil administration on acetaminophen-induced tissue injury including hepatotoxicity and nephrotoxicity. This study investigated the ability of Nigella sativa linn oil to alleviate the acetaminophen-induced hepatic and renal functions impairments and oxidative stress in rats. Exposure to acetaminophen at their recommended dose to rats led to an alteration of hepatic and renal parameters and antioxidant capacities.

Acetaminophen has a reasonable safety profile in therapeutic doses, its overdose remains the most important cause of liver injury and even death in many parts of the world among all drug toxicities (Yayla et al., 2014). Hepatotoxic and nephrotoxic effects of Acetaminophen overdose occur by a complex sequence of events (Hinson et al., 2010). Acetaminophen toxicity in animals and man produces hepatic necrosis and a depletion of both mitochondrial and cytosolic pools of reduced glutathione. Kidney is the second target organ of Acetaminophen toxicity although nephrotoxicity may exist in the absence of hepatotoxicity following Acetaminophen overdose (Gulnaz et al., 2010).

The acetaminophen-treated group which was subjected to oral administration of $500 \mathrm{mg} / \mathrm{kg}$ of acetaminophen for induction of 
hepatotoxicity and nephrotoxicity showed significant increase in liver enzymes (ALT, AST and TB) and renal biomarkers (serum creatinine and blood urea) when compared to positive control group. These results agreed with (Gopi et al., 2010 and Pal et al., 2011).

Serum ALT is considered a highly sensitive and specific biomarker of hepatotoxicity (Schefer et al., 2011). Also, increase in serum transaminases (AST and ALT) levels after acetaminophen administration highly signifies hepatocellular injury (Pratt et al., 2012). Moreover, elevation in liver enzymes reflected liver cell damage and could be attributed to tissue breakdown, permitting the escape of intracellular enzymes from cytosol into the blood. When liver plasma membrane gets damaged, a variety of enzymes normally located in the cytosol are released into the circulation (Jaswal and Shukla, 2015).

Renal biomarkers (urea and serum creatinine) significantly increased as compared with the positive control group, a reactive metabolite of acetaminophen that caused oxidative damadge to tissues. This might be the reason for its reno-toxic effects (Gopi et al., 2010).

Creatinine, a more reliable renal function marker, is a breakdown product of creatine phosphate in muscle metabolism at a constant rate. Increased creatinine concentration reflects the reduced glomerular filtration rate. An indication of renal dysfunction which is greatly reinforced our results as the acetaminophen-treated group showed an elevation in creatinine level and this also reflects the ameliorative role of $\mathrm{N}$. sativa in reducing this dysfunction by decreasing creatinine level in acetaminophen $+\mathrm{NsL}$ oil-treated group (Ismail et al., 2014). On the same basis, urea, a major nitrogenous end product of protein/amino acid catabolism, also acts as a renal function marker as its elevation indicates impaired glomerular filtration and this also coincides with our results.

In the present work, the acetaminophen-treated group showed significant increase in TNFa when compared to positive control group. These results agreed with the results of Singh and (Chowdhary, 2014). These findings supported the induction of oxidative stress in rat kidney by acetaminophen which was in concomitant with (Ilbey et al., 2009). (Ghosh et al., 2010) reported increased oxidative stress and TNF-alpha production in rat tissues.

In the present work, the acetaminophen-treated group showed significant increase in MDA in the liver and kidney tissues when compared to positive control group which indicated occurrence of oxidative stress in this group. These results agreed with (Kleniewska et al., 2013).

The histopathological results of the current work supported the toxic effect of acetaminophen on the liver administered with previous dose as the acetaminophentreated group showed expanded portal tracts with markedly dilated blood vessels, dilated central vein with peri-venular cellular infiltrate, scattered apoptotic hepatocytes and scattered hepatocytes with micro-vesicular steatosis, without underlying fibrosis. These changes coincide with (Hussain et al., 2014).

Also, a histopathological evidence of renal damage was observed after 


\section{HAMED MOHAMMED OSMAN et al.}

administration of acetaminophen in the previous dose in the form of distorted hypercellulr glomeruli with interstitium showing fibrous band, minimal cellular infiltrate and marked vacuolar degeneration of tubular epithelium. These results were in agreement with (Canayakin et al., 2016).

Moreover, the results of the current work revealed mild glomerular and peritubular fibrosis due to increased collagen fibers in Masson`s trichrome-stained sections of kidney in acetaminophentreated group. These results agreed with (Elkhateeb et al., 2015).

Surazynski et al. 2008) stated that collagen is not only a structural component of extracellular matrix. It has been recognized as a ligand for integrin receptors, which play an important role in signaling that regulate ion transport, lipid metabolism, kinase activation and gene expression. Therefore, changes in the quantity, structure and distribution of collagens in tissues may affect cell signaling, metabolism and function.

In the present work, the immunofluorescence staining of liver sections of acetaminophen treated group showed marked cell membrane expression of TGF $\beta$ in hepatocytes and cytoplasmic reactivity in stellate-shaped cells compared to positive control group that showed moderate cell membrane reactivity in peri-venular hepatocytes these results agreed with (Elsakka et al., 2016).

The immunofluorescence staining of kidney sections of acetaminophen-treated group showed moderate reactivity in glomeruli and tubules compared to positive control group that showed mild reactivity in glomeruli and tubules. These results agreed with (L?pez-Hern?ndez and L?pez-Novoa, 2012).

In the current work, acetaminophen + NsL oil-treated group showed significant increase in liver enzymes (ALT, AST and $\mathrm{TB}$ ) and renal biomarkers (serum creatinine and blood urea) when compared to positive control group. These results agreed with (Hasan et al., 2016), but these parameters when compared to acetaminophen treated group showed significant decrease .

The therapeutic and protective effects of NS in models of hepatotoxicity failure have been elucidated in various studies. The NS effect on alanine aminotransferase (ALT), aspartate aminotransferase (AST), LDH, total antioxidant capacity (TAC), catalase (CAT), myeloperoxidase (MPO), total oxidative status (TOS) and oxidative stress index (OSI) denotes its hepatoprotective activity (Islam et al., 2017).

Ahmed and Eid ( 2010) reported the role of Nigella sativa in preventing carbon tetrachloride (CCl4)-induced liver toxicity. The results showed that Nigella sativa oil decreased the levels of the elevated serum of liver enzymes considerably, and could improve the state of oxidative stress induced by $\mathrm{CCl} 4$. Regarding renal failure, early studies have shown that the predominant recovery mechanism of the acute kidney injury was mediated through therapeutical and protective effects of NS. (Saleem et al., 2012) reported that nephroprotective effect of NsL oil against gentamycininduced nephrotoxicity in rabbits where NsL oil lowers the values of serum creatinine and blood urea nitrogen, 
decreases the tubular necrosis score, and prevents the degenerative changes in kidney tissues.

In the present work, the acetaminophen + NsL oil-treated group showed significant decrease in serum $\mathrm{TNF} \alpha$ compared to acetaminophen treated group which supported that NS exerted antiinfilammatory and antioxidant effects. These results agreed with (Islam et al., 2017). Volarevic et al. (2011) demonstrated that the secreted antiinflammatory cytokines were associated with decrease in secretion of inflammatory cytokines like TNF $\alpha$. Also, the acetaminophen + NsL oil-treated group showed significant decrease in MDA in the liver and kidney tissues compared to acetaminophen-treated group. These results agreed with (Canayakin et al., 2016).

In the present work, the histopathological results of the liver tissue of acetaminophen + NsL oil-treated group showed expanded portal tracts with markedly dilated blood vessels, markedly dilated central veins, markedly congested blood sinusoids and vacuolated hepatocytes. These results agreed with Ghadlinge et al. (2014) who stated that co-administration of NS oil with paracetamol signi?cantly reduces scores of degeneration, necrosis and ?brosis.

Also, the histopathological results of the kidney tissue of the same group showed distorted hypercelluler glomeruli with mild vacuolar degeneration of tubular epithelium. These results agreed with the findings of Canayakin et al. (2016).

It was noted that the histopathological results of the current work supported the biochemical results of acetaminophen + NsL oil-treated group through appearance of partial improvement and evidence of some regeneration of both liver and kidney tissues when compared to acetaminophen-treated, and expression of TGF $\beta$ in hepatocytes was improved in acetaminophen + NsL oil-treated compared to acetaminophen-treated group which also supported both partial improvement of the biochemical results and evidence of some regeneration of liver tissues through the histopathological results.

\section{CONCLUSION}

Our results indicated that the NsL oil alleviated the toxic effects of acetaminophen on the liver and kidney including the histopathological and biochemical changes as well as the oxidative damage. The curative effect of NsL oil could be due to its antioxidant potential by scavenging the free radicals. So, patients using acetaminophen for long times should be checked regularly for their liver and kidney functions. Our study revealed that usage of TGF $\beta$ as a candidate marker for diagnosis and prognosis of both chronic liver and kidney diseases also as a target for their treatment. Also, other studies on dosedependent effects of NSL oil are also recommended.

\section{REFERENCES}

1. Abdel-Bakky MS, Hammad MA, Walker LA and Ashfaq MK. (2011): Tissue factor dependent liver injury causes release of retinoid receptors (RXR-alpha and RAR-alpha) as lipid droplets. Biochem Biophys Res Commun., 410 (1):146-51.

2. Ahmed MM and Eid A S. (2010): Protective effect of pomegranate peel ethanol extract 


\section{HAMED MOHAMMED OSMAN et al.}

against ferric nitrilotriacetate induced renal oxidative damage in rats. J Cell and Mol Biol., $7(2) \& 8(1): 35-43$.

3. Al-Khalaf MI and Ramadan KS. (2013): Oxidants and Antioxidants Status in Bronchial Asthma. Asian Journal of Applied Sciences, 1(4): 123-133.

4. Amini FG, Rafieian-Kopaei M, Nematbakhsh M, Baradaran A and Nasri H. (2012): Ameliorative effects of metformin on renal histologic and biochemical alterations of gentamicin-induced renal toxicity in Wistar rats. J Res Med Sci., 17(7): 621-5.

5. Assayed ME. (2010): Radioprotective effects of black seed (Nigella sativa) oil against hemopoietic damage and immunosupression in gamma-irradiated rats. Immuno pharmacl. Immunotoxicol., 32 (2); 284-296.

6. Bancroft, J.D., Stevens, A. and Turner, D.R. (1996): Theory and practice of histological techniques, 4th edn, Churchil, Livingston, San Francisco, Tokyo, p, 766.

7. Bunchorntavakul C and Reddy KR (2013): Acetaminophen-related hepatotoxicity. Clin Liver Dis., 17:587-607.

8. Canayakin D, Bayir Y, Kilic Baygutalp N, Sezen Karaoglan E, Atmaca HT, Ozgeris F, Keles M and Halici Z (2016): Paracetamolinduced nephrotoxicity and oxidative stress in rats: the protective role of Nigella sativa. Pharm Biol., 54(10): 2082-2091.

9. Cemek, M., Büyükokuroglu, M.E., Bay?roglu, F., Koc, M. and Arora, R. (2008): Herbal Radiomodulators: Applications inMedicine, Homeland Defence and Space. Pbl. CABI, Wallingford, UK, p. 56.

10. Elkhateeb A, El Khishin I, Megahed O and Mazen F (2015): Effect of Nigella sativa Linn oil on tramadol-induced hepato- and nephrotoxicity in adult male albino rats. Toxicol Rep., 2:512-519.

11. Elsakka E., Abd-Allah G., Abulsoud A., Mansour A. and Abdel Raheem S. (2016): Growth Factor Receptors and Liver Injury. International Journal of Biochemistry Research \& Review. 12(3): 1-10.
12. Fossati P, Prencipe L and Berti G, (1983): Enzymatic creatinine assay, a new colorimetric method based in hydrogen peroxide measurement. Clin.Chem., 29: 1494.

13. Friedman, S.L. (2008): Hepatic fibrosis overview. Toxicology, 254:120-129.

14. Ghadlinge MS., Jugalkishor B.J., Rakhamaji D., Chandane1, Rakesh R.J. and Rama R.B. (2014): A study of effect of Nigella sativa oil in paracetamol induced hepatotoxicity in albino rats. International Journal of Basic \& Clinical Pharmacology, 3(3): 539.

15. Ghosh J., Das J., Manna P. and Sil PC. (2010): Acetaminophen induced renal injury via oxidative stress and TNF-alpha production: therapeutic potential of arjunolic acid. Toxicology, 268: 8-18.

16. Ghosh SS, Gehr TW and Ghosh S. (2014): Curcumin and chronic kidney disease (CKD): major mode of action through stimulating endogenous intestinal alkaline phosphatase. Molecules, 19:20139-56.

17. Gopi K. S., Gopala R. A., Jyothi K. and Kumar B. A. (2010): Acetaminophen-induced Hepato- and Nephrotoxicity and Amelioration by Silymarin and Terminalia chebula in Rats, Toxicol Int., (2): 64-66.

18. Grosser T, Smyth $E$ and FitzGerald GA (2011): Anti-inflammatory, antipyretic, and analgesic agents; Pharmacotherapy of Gout: introduction. Goodman \& Gilman's The Pharmacological Basis of Therapeutics. 12th Edition. New York: McGraw Hill Medical Publication, pp. 959-1004.

19. Gulmez SE, Larrey D, Pageaux GP, Lignot

S, Lassalle R, Jove J, Gatta A, McCormick PA, Metselaar $\mathbf{H}$, Moubouteiro $\mathbf{E}_{\text {, }}$ Thorburn $\mathbf{T}$, Bernal Wetoubouls-Vafiadis the de ries $\mathbf{M}$, Berezichouf, Montastruc Jtur, Horsmans $Y$,

Salvo F, Hamoud F, Micon S, Droz-Perroteau C, Blin P and Moore N.

(2013): Transplantation for acute liver failure in patients exposed to NSAIDs or paracetamol (acetaminophen):
case-poptilation SALT study. Drug Saltinational 135-44.

20. Gulnaz H, Tahir M, Munie B and Sami W. (2010): Protective effects of garlic oil on acetaminophen induced nephrotoxicity in male albino rats. Biomedica., 26: 9-15.

21. Hasan MN., Khan RA., Nasiruddin M. and Khan AA. (2016): Ameliorative Effect of 
Nigella sativa Oil against Paracetamol Induced Hepatic and Renal Damages in Rats. British Journal of Pharmaceutical Research, 13(3): 110.

22. Hinson JA, Roberts DW and James LP. (2010): Mechanisms of acetaminophen-induced liver necrosis. Handb Exp Pharmacol., 196:369-405.

23. Hussain L, Ikram J, Rehman K, Tariq M, Ibrahim $M$ and Akash MS, (2014): Hepatoprotective effects of Malva sylvestris L. against paracetamol-induced hepatotoxicity. Turk J Biol., 38: 396-402.

24. Ijaz, H., Tulain, U.R., Qureshi, J., Danish, Z., Musayab, S., Akhtar, M.F., Saleem, A., Khan, KA., Zaman, M., Waheed, I., Khan, I, and Abdel-Daim, M. (2017): Review: Nigella sativa (prophetic medicine): a review. Pak. J. Pharm. Sci., 30, 229-234.

25. Ilbey, Y.O. Ozbek, E. and Cekmen, M. (2009): Melatonin prevents acetaminopheninduced nephrotoxicity in rats. International Urology and Nephrology, 41: 695-702.

26. Islam MT, Guha B, Hosen S, Riaz TA. and Shahadat S. (2017): Nigellalogy: A Review on Nigella Sativa. MOJ Bioequiv Availab., 3(6): 00056.

27. Ismail HAA, Hamza RZ and El-Shenawy NS. (2014): Potential protective effects of blackberry and quercetin on sodium fluorideinduced impaired hepato-renal biomarkers, sex hormones and hematotoxicity in male rats. J Appl Life Sci Int., 1(1): 1-16.

28. Jaswal A and Shukla S. (2015): Therapeutic efficacy of Nigella sativa Linn. Seed extract against $\mathrm{CCl} 4$ induced hepatic injury in wistar rats. Indian J Exp Biol., 53(1):44-50.

29. Kandeel A, Genedy M, El-Refai S, Funk AL, Fontanet $A$ and Talaat $M$. (2017): The prevalence of hepatitis $\mathrm{C}$ virus infection in Egypt 2015: implications for future policy on prevention and treatment. Liver Int., 37:45-53.

30. Kleniewska, P., Piechota-Polanczyk, A. Michalski, L., Michalska, M., Balcerczak, E., Zebrowska, M. and Goraca, A. (2013): Influence of block of NF-kappa B signaling pathway on oxidative stress in the liver homogenates. Oxid. Med. Cell Longev., 2013:308-358.

31. Kotb, A.M., Simon, O., Blumenthal, A., Vogelgesang, S., Dombrowski, F., Amann, K., Zimmermann, U., Endlich, $\mathrm{K}$ and Endlich, N. (2016): Knockdown of ApoL1 in zebrafish larvae affects the glomerular filtration barrierand the expression of Nephrin. PLoS One, 11: e0153768.

32. L?pez-Hern?ndez, F.J. and L?pez-Novoa, J.M. (2012): Role of TGF- $\beta$ in chronic kidney disease: an integration of tubular, glomerular and vascular effects.Cell and Tissue Research, 347: 141-154.

33. Mallay H.T. and Evelyn K.A. (1937): Estimation of serum bilirubin level with the photoelectric colorimeter, J. Biol. Chem., 119; 481-484.

34. Nasri H. (2013): World kidney day 2013: acute kidney injury; a public health aware. Iran J Public Health, 42:338-40.

35. Ohkawa, H., Ohishi, N. and Yagi, K. (1979): Assay for lipid peroxides in animal tissues by thiobarbituric acid reaction. Anal. Biochem., 95: 351-358.

36. Orsonneau J, Massoubre $\mathrm{C}$ and Cabanes $\mathrm{M}$, (1992): Simple and sensitive determination of urea in serum and urine. Clin. Chem., 38- 619.

37. Pal DR, Nahar S, Rimi KR, Talukder SA, Hossain MM, Paul PC and Eva EO. (2011): Hepatoprotective Effect of Nigella Sativa Linn (Kalajira) On Paracetamol-induced Liver Damage. Bangladesh Medical Journal, 40(3): 52-54.

38. Parola, M.,Marra, F. and Pinzani, M. (2008): Myofibroblast like cells and liver fibrogenesis: emerging concepts in a rapidly moving scenario. Mol. Aspect Med., 29:58-66.

39. Pettie J and Dow M. (2013): Assessment and management of paracetamol poisoning in adults. Nurs Stand., 27:39-47.

40. Pratt DS, Kaplan MM, Wolkoff AW, Pratt DS and Kaplan MM, In: Kasper DL, Braunwald E, Fauci AS, Hauser SL, Longo DL and Jameson JL. (editors). (2012): Harrison's Principles of internal medicine, 18th 


\section{HAMED MOHAMMED OSMAN et al.}

ed: McGraw Hill, USA, 261, 2531-2532, 2527 -2530 .

41. Rafieian-Kopaie, M and Nasri, HR. (2013): recombinant human erythropoietin reduces rhabdomyolysis-induced acute renal failure in rats. Injury, 44:1662.

42. Reitman $S$ and Frankel S, (1957): A colometric method for the determination of serum glutamic oxalacetic and glutamic pyruvic transaminases, Am.J. Clin. Pathol., 28 (1) 5663.

43. Saleem U., Ahmed B., Rehman K., Mahmood S., Alam M. and Erum A. (2012): Nephro-protective effect of vitamin $\mathrm{C}$ and Nigella sativa L. oil ongentamycin-associated nephrotoxicity in rabbits, Pak. J. Pharm. Sci., 25 (4) 727-730.

44. Schefer $K$, Hage $R$, Ringe $S$ and Schwarzwald C. (2011): Laboratory, electrocardiographic, and echocardiographic detection of myocardial damage and dysfunction in an Arabian mare with nutritional masseter myodegeneration. J Vet Intern Med., 25(5):1171-80.

45. Singh, B. and Chowdhary, M. (2014): Stem Cell: Pluripotent Cell or Reserve cell? Indian Journal of Clinical Anatomy and Physiology., 17: 34- 40 .

46. Surazynski A., Miltyk W., Palka J. and Phang J.M. (2008): Prolidasedependentregulation of collagen biosynthesis, Amino Acids, 35 (4): 731-738.
47. Thomas L. (1998): Alanine amino-transferase (ALT), aspartate amino-trasferase (AST), in: Thomas L (Ed.), Clinical Laboratory Diagnostics, 1st ed., TH-Books Verlagsgesellschaft, Frankfurt, pp. 55-56.

48. Trautwein C, Friedman SL, Schuppan D and Pinzani M. (2015): Hepatic fibrosis: concept to treatment. J Hepatol., 62:15-24.

49. United state pharmacopeoa (USP) (2007): 31, soft edition.

50. Vanamala U, Elumalai A, Eswaraiah MC and Shaik A. (2012): An updated review on diuretic plants-2012. Int J Pharm Biol Arch., 3:29-31.

51. Volarevic, V., Ljujic, B. and Stojkovic, P. (2011): Human stem cell research and regenerative medicine-Present and future. $\mathrm{Br}$. Med. Bull., 99: 155-168.

52. Yayla M, Halici Z, Unal B, Bayir Y, Akpinar E and Gocer F. (2014): Protective effect of et-1 receptor antagonist bosentan on paracetamol induced acute liver toxicity in rats. Eur J Pharmacol., 726: 87-95. 
EVALUATION OF THE POSSIBLE CURATIVE EFFECT OF NIGELLA... 303

\section{تقييم التأثير العلاجى المحتمل لزيت الحبة السوداء على كل التباء}

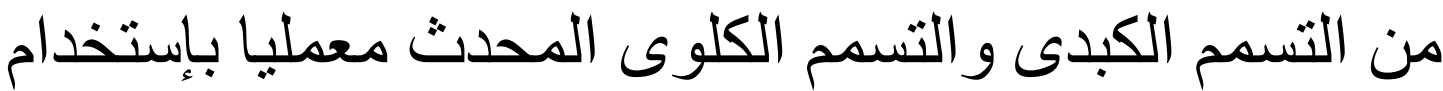

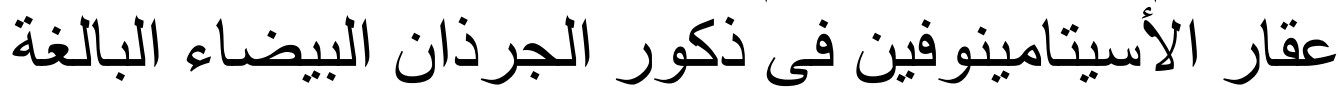

حامد محمد عثمان- سعد محمد محمد ـ سيا عبد الرحيم سيد*ـ أشرف عبد العاطى عمارة قسمى الفسيولوجيا الطبية والباثولوجيا** كلية طب الازهر

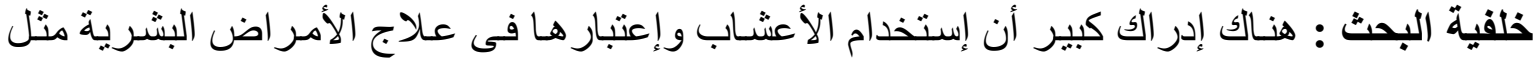
التسمم الكبدى و التسمم الكلوى. وتعتبر الحبة السوداء واحدة من أهم النباتات الطبية التى لها تأثير قوى كمضاد للأكسدة.

الهـف من البحث: در اسة التأثير العلاجى المحتمل لزيت الحبة السوداء على كل من التسمم الكبدى و التسمم الكلوى المحدث معمليا بإستخدام عقار الأسيتامينوفين فى ذكور الجرذان البيضاء البالغة. مواد وطرق البحث: إستخدم في هذا البحث خمسون جرذا أبيضـا بالغـا من فصيلة محلية ، و وقد تم إحداث التسمح الكبدي الكلوي بإستخدام عقار الأسيتامينوفين. وفي نهاية التجربة (أربعة و عشرين يومـا) تم أخذ عينات من الدم لقياس بعض وظائف الكبد و الكلي و أيضـا قياس TNFa وكذللك تم أخذ عينـات من نسيج كل من الكبد و الكلي لفحصها مجهريا ولعمل بعض القياسات الخاصة بحدوث عملية الأكسدة داخل هذه الأنسجة.

النتائج: أحدث عقار الأسيتامينوفين زيـادة في وظائف الكبد و الكلي و أيضـا فى كل المقاييس التي تم در استها فى هذا البحث وتأكيد هذه النتائج بفحص نسيج كلا من الكبد و الكلي مجهريـا ، بينمـا أحدث زيت الحبة السوداء نقصا في المقاييس التي تم در استها.

الاستتتاج: العلاج بزيت الحبة السوداء لله دور فعال في إلتئام كل من نسيجى الكبد والكلي في الفشل الكبدي الكلوي المحدث تجريبيا بعقار الأسيتامينوفين. 